\title{
A new commentary in the vernacular
}

\begin{tabular}{|c|c|}
\hline \multicolumn{2}{|c|}{$\begin{array}{l}\text { Book Title: } \\
\text { Amazwi omprofethi omncane } \\
\text { uMikha [A commentary on } \\
\text { the book of Micah in isiZulu] }\end{array}$} \\
\hline \multicolumn{2}{|l|}{ Book Cover: } \\
\hline $\begin{array}{l}\text { Amazui } \\
\text { omphrofe } \\
\text { omncane } \\
\text { unilha }\end{array}$ & thif \\
\hline 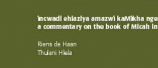 & \\
\hline $\begin{array}{l}\text { Authors: } \\
\text { Riens de Haan } \\
\text { Thulani Hlela }\end{array}$ & \\
\hline \multicolumn{2}{|c|}{$\begin{array}{l}\text { ISBN: } \\
9781920620219\end{array}$} \\
\hline $\begin{array}{l}\text { Publisher: } \\
\text { Cluster Public } \\
\text { Pietermaritzb } \\
\text { R100.00* } \\
\text { *Book price at t }\end{array}$ & $\begin{array}{l}\text { tions, } \\
\text { me of review }\end{array}$ \\
\hline \multicolumn{2}{|c|}{$\begin{array}{l}\text { Review Title: } \\
\text { A new commentary in the } \\
\text { vernacular }\end{array}$} \\
\hline \multicolumn{2}{|c|}{$\begin{array}{l}\text { Reviewer: } \\
\text { Bob Wielenga }{ }^{1,2}\end{array}$} \\
\hline \multicolumn{2}{|c|}{$\begin{array}{l}\text { Affiliations: } \\
{ }^{1} \text { KwaZulu-Natal Missionary } \\
\text { and Bible College, } \\
\text { South Africa }\end{array}$} \\
\hline \multicolumn{2}{|c|}{$\begin{array}{l}{ }^{2} \text { Theology Faculty North- } \\
\text { West University, } \\
\text { Potchefstroom Campus, } \\
\text { South Africa }\end{array}$} \\
\hline \multicolumn{2}{|c|}{$\begin{array}{l}\text { Corresponding author: } \\
\text { Bob Wielenga, } \\
\text { bwielenga@outlook.com }\end{array}$} \\
\hline \multicolumn{2}{|c|}{$\begin{array}{l}\text { How to cite this book review: } \\
\text { Wielenga, B., 2018, 'A new } \\
\text { commentary in the } \\
\text { vernacular', In die Skriflig } \\
52(1) \text {, a2328. https://doi. } \\
\text { org/10.4102/ids.v52i1.2328 }\end{array}$} \\
\hline \multicolumn{2}{|l|}{ Read online: } \\
\hline 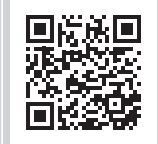 & $\begin{array}{l}\text { Scan this QR } \\
\text { code with your } \\
\text { smart phone or } \\
\text { mobile device } \\
\text { to read online. }\end{array}$ \\
\hline
\end{tabular}

This is the third volume in a new series of commentaries in isiZulu on the minor prophets of the Old Testament, following on the volumes on Malachi and Jonah. It is a series of commentaries based upon sound biblical scholarship, but focused on its use in the Bible ministries of the church. The authors, based in the GKSA of Southern KZN as ordained ministers, aim at increasing the Bible knowledge of the readers to help them to prepare their sermons on Micah and to demonstrate the significance of this ancient prophet for their own times in the present African context among isiZulu speakers.

These commentaries are written as part of the Africanisation process that is taking place at the School of Theology at UKZN in Pietermaritzburg. The present volume on Micah demonstrates that this process does not lead to a lowering of academic standards. The close attention paid by the authors to questions related to the historical background of Micah is a case in point. They divide the book into three parts (chapters 1-2, 3-5 and 6-7), and carefully sketch the historical context of each section in relation to the different stages of the Assyrian onslaught on Judah and Israel from 734 to $701 \mathrm{BCE}$. The fact that one of the authors is a Bible translator by training, ensures that the somewhat difficult Masoretic text of Micah receives an accessible translation in modern isiZulu. Added to the book is a list with Hebrew words that requires the special attention of the reader of Micah, justifying the interpretation chosen. The usual canonical questions are adequately addressed. The authors conscientiously refer to differences of opinion among commentators. A list with references to other commentaries and Bible translations has been added, and even digital sources are mentioned. Scripture and topical indices are also included.

To make this volume useable in the Bible ministries of the church, the authors have developed an effective step-by-step teaching strategy. Each section starts with a summary of the preceding section, so that the user of this commentary does not lose sight of the line of argumentation the authors are developing. The blocks of information of a geographic, archaeological and homiletic nature framed separately from the text of the commentary, are also very useful. The authors try intentionally to create terminology and concepts in isiZulu to help the reader to reflect on the text in the vernacular, and not in a second or even third language which creates sometimes confusion and an unnecessary distance from the text.

The influence of the Dutch Old Testament scholar A.S. van der Woude is noticeable. Logo-technical structure analysis has, incidentally (p.97), also found its way into this commentary which reminds one of the Afrikaans Old Testament scholar C.J. Labuschagne. Among the literature references one finds titles by authors such as J.A. Nogalski who work with the newer literary criticism on the Book of the Twelve.

This publication, which is very affordable, can be recommended. It provides a worthy contribution to the development of biblical scholarship in the vernacular on the African continent in which the Bible text is taken extremely seriously. It opens the way to hear God speaks his Word through Micah to people who are as much in need to hear it as his original audience. 